\title{
PENGARUH DAYA TARIK BRAND AMBASSADOR DAN DAYA TARIK IKLAN TELEVISI TERHADAP KEPUTUSAN PEMBELIAN SHAMPO MEREK PANTENE PADA MASYARAKAT LABUHANBATU UTARA
}

\author{
Zuriani Ritonga \\ Sekolah Tinggi Ilmu Ekonomi Labuhanbatu, Sumatera Utara - Indonesia \\ E-mail :zuriani2017@gmail.com
}

\begin{abstract}
ABSTRAK
Tujuan penelitian ini adalah: 1) Untuk mengetahui pengaruh daya tarik brand ambassador terhadap keputusan pembelian shampo merek pantene pada masyarakat labuhanbatuutara, 2) untuk mengetahui pengaruh daya tarik iklan terhadap keputusan pembelian shampo merek pantene pada masyarakat labuhanbatuutara.Hipotesis penelitian adalah variabel daya tarik brand ambassador berpengaruh signifikan terhadap keputusan pembelian shampo merek pantene pada masyarakat labuhanbatuutara, variabel daya tarik iklan berpengaruh signifikan terhadap keputusan pembelian shampo merek pantene pada masyarakat labuhanbatuutara.Populasi dari penelitian ini adalah masyarakat labuhanbatuutara. Hasil penelitian menunjukkan bahwa: 1) daya tarik brand ambassador berpengaruh positif dan signifikan terhadap keputusan pembelian shampo merek pantene pada masyarakat labuhanbatuutara, daya tarik iklan berpengaruh positif dan signifikan terhadap keputusan pembelian shampo merek pantene pada masyarakat labuhanbatuutara.
\end{abstract}

Kata kunci: Daya Tarik Brand Ambassador, Daya Tarik Iklan, Keputusan Pembelian

\section{Pendahuluan}

Di zaman yang sudah semakin modern, persaingan bisnis yang terjadi semakin dinamis, kompleks dan ada banyak tantangan yang dihadapi perusahaan pula untuk mendapatkan cara terbaik untuk merebut serta mempertahankan pangsa pasar. Tantangan yang dihadapi oleh perusahaan adalah bagaimana memperkenalkan produk yang dimiliki kepada calon konsumen. Tantangan tersebut tidak hanya sampai pada perkenalan produk tetapi perusahaan harus membuat produknya tetap eksis dipasaran, mengembangkan menjadi lebih besar dengan memberikan inovasi baru sehingga membuat konsumen memiliki banyak pilihan.

Apabila tantangan ini semua dapat dilewati dengan baik, maka perusahaan akan mencapai titik puncak dan mendapatkan keuntungan. Tahap persuasi (membujuk) tidak dapat dipisahkan di dalam upaya menarik perhatian calon konsumen. Pemberian informasi yang lengkap dan mendetail sangat diperlukan karena dari situlah calon konsumen dapat mengetahui produk yang ditawarkan. Perusahaan saat ini berlomba - lomba untuk menarik perhatian calon konsumen di dalam menarik perhatiannya melalui sarana iklan. 
Periklanan pada dasarnya adalah alat yang digunakan dalam proses pemberian informasi kepada khalayak sehingga akan terjadi komunikasi persuasif didalamnya. Periklanan memiliki tiga (3) tujuan di dalam keperluan utamanya, yaitu sebagai pemberian informasi, membujuk para konsumen untuk mencoba produk yang ditawarkan dan mengingatkan produk yang diiklankan kepada calon konsumen. Perusahaan - perusahaan besar di dalam beriklan lebih banyak menggunakan televisi (TV) sebagai medianya. Televisi dipilih sebagai sarana beriklan karena televisi memiliki kekuatan yaitu dari sisi audio dan visual yang ditampilkan. Perusahaan akan dapat dengan mudah menyasar pasar dengan mendemonstrasikan produk yang ditawarkan dan akan membuat calon konsumen menjadi tertarik akan produk tersebut.

Calon konsumen dengan adanya visualisasi yang ditampilkan akan dapat mengimajinasikan apakah produk tersebut sesuai dengan kebutuhan dan keinginan mereka. Beriklan dengan media televisi dapat menjangkau masyarakat luas secara individu karena tingkat pemahaman akan apa yang didemonstrasikan oleh perusahaan antara individu satu dengan lainnya pasti berbeda - beda. Keuntungan lainnya menggunakan televisi sebagai media beriklan adalah intensitas beriklan yang dapat dilakukan berulang kali yang secara tidak langsung akan mengingatkan calon konsumen sekaligus mengaktifkan ingatan mereka akan produk yang ditawarkan.

Maka dari itu, di dalam beriklan perusahaan haruslah sekreatif mungkin karena dengan semakin kreatif akan meningkatkan niat dan minat calon konsumen kepada produk tersebut. Sisi kreatif yang ditampilkan perusahaan antara lain dengan menggunakan brand ambassador dan daya tarik iklan. Saat ini, masyarakat sudah banyak disuguhi berbagai macam iklan produk melalui media - media yang ada seperti televisi, radio, koran, dan lainnya. Salah satu strategi pemasaran yang dilakukan oleh perusahaan adalah menggunakan brand ambassador.

Pemilihan brand ambassador dilatarbelakangi oleh citra positif yang dibawa oleh brand ambassador. Brand ambassador dipilih oleh perusahaan sebagai simbolisasi atau penanda untuk mewakili keinginan dan kebutuhan dari calon konsumen. Brand ambassador memang tidak semuanya menggunakan selebriti sebagai modelnya tetapi dalam penelitian brand ambassador yang dipilih adalah dengan menggunakan selebriti. Selebriti dipilih sebagai orang yang mewakili perusahaan melalui produk yang ditawarkan karena memiliki daya tarik, popularitas, bakat dan kharisma yang kuat. Brand ambassador haruslah memiliki gairah, mau dan sanggup memperkenalkan sampai dengan sukarela memberikan informasi kepada calon konsumen tentang brand dari produk yang ditawarkan.

Selebriti adalah tokoh (atlet, artis, dan lain - lainnya) yang terkenal karena berprestasi dibidangnya masing - masing. Selebriti didefinisikan lebih luas lagi sebagai individu yang telah diliput oleh media. Perusahaan memilih selebriti tertentu sebagai brand ambassador sebagai bentuk representasi dari produk yang ditawarkan dan memiliki harapan bahwa selebriti sebagai brand ambassador tersebut mampu memberikan pengaruh kepada calon konsumen. Brand ambassador haruslah melekat dengan produk yang dibintanginya (produk yang ditawarkan oleh perusahaan) dan menjadi bagian dari gaya hidupnya.

Seorang ambassador dituntut untuk memiliki loyalitas yang tinggi terhadap merek produk yang dibintanginya. Seorang brand ambassador dituntut pula untuk selalu 
mengkomunikasikan produk kepada calon konsumen dengan pendekatan yang berbeda - beda dan sekreatif mungkin. Pengkomunikasian ini juga harus direalisasikan pada kehidupannya sehari - hari, mereka seakan - akan berkampanye tanpa diketahui oleh masyarakat. Keberhasilan suatu produk juga ditentukan dengan seberapa besar pengaruh yang diberikan oleh brand ambassador tersebut.

Seorang brand ambassador pada dasarnya haruslah sesuai dengan produk yang diwakilkan supaya ada kesesuaian dengan target pasar. Salah satu iklan yang menggunakan brand ambassador adalah shampo Pantene. Shampo Pantene merupakan salah satu merek dari produk PT Unilever Indonesia Tbk yang diasosiasikan sebagai shampo anti-ketombe.

Berikut ini data Top Brand Index 2012-2014 kategori perawatan pribadi dalam produk shampo:

Tabel 1.1 Top Brand Index Produk Shampo di Indonesia 2012-2014

\begin{tabular}{|l|l|l|l|}
\hline Merek & 2012 & 2013 & 2014 \\
\hline Pantene & $29,2 \%$ & $27,3 \%$ & $25,1 \%$ \\
\hline Clear & $20,3 \%$ & $23,1 \%$ & $22,5 \%$ \\
\hline Sunsilk & $20,5 \%$ & $18,5 \%$ & $16,5 \%$ \\
\hline Lifebouy & $11,7 \%$ & $11,4 \%$ & $10,9 \%$ \\
\hline Rejoice & $6,1 \%$ & $5,0 \%$ & $4,8 \%$ \\
\hline Dove & $5,5 \%$ & $5,5 \%$ & $6,1 \%$ \\
\hline Zinc & $2,3 \%$ & $3,7 \%$ & $4,6 \%$ \\
\hline Emeron & $1,2 \%$ & $1,0 \%$ & $2,5 \%$ \\
\hline
\end{tabular}

Sumber: http://www.topbrand-award.com

Berdasarkan tabel 1.1 di atas dapat diketahui bahwa Top Brand Index shampo pantene pada tahun 2012 sebesar 29,2\%, pada tahun 2013 mengalami kenaikan menjadi sebesar 27,3\%, kemudian mengalami penurunan pada tahun 2014 menjadi 25,1\%. Hal ini menunjukkan brand image pantene dalam benak konsumen masih tinggi dibandingkan dengan produk pesaingnya yaitu clear.

Keputusan pembelian adalah bagian dari perilaku konsumen yang sampai pada tahap pembelian produk berupa barang atau jasa. Pengambilan keputusan dalam pembelian merupakan bagian dari kondisi psikologis seseorang untuk mendapatkan produk baik barang maupun jasa yang ditawarkan perusahaan. Pengambilan keputusan pembelian ini dipengaruhi oleh berbagai tahapan dari mulai pengenalan masalah yaitu apa yang menjadi kebutuhannya sampai pada perilaku yang ditimbulkan pasca pembelian.

Berdasarkan hal-hal yang telah diuraikan tersebut diatas, penyusun tertarik untuk melakukan penelitian tentang: "Pengaruh daya tarik brand ambassador dan daya tarik iklan televisi terhadap keputusan pembelian shampo merek pantene pada masyarakat labuhanbatuutara." 


\section{Pembatasan Masalah}

Penulis membatasi masalah hanya pada produk shampo pantene untuk dilakukan penelitian. Penulis membatasi penelitian pada segala sesuatu yang berhubungan dengan daya tarik brand ambassador dan daya tarik iklan televisi terhadap keputusan pembelian shampo merek pantene pada masyarakat labuhanbatuutara.

\section{Perumusan Masalah}

Latar belakang yang sudah dipaparkan di atas menggambarkan mengenai daya tarik brand ambassador dan daya tarik iklan terhadap keputusan pembelian. Rumusan masalah yang diambil adalah :

- Apakah daya tarik brand ambassadormemiliki pengaruh terhadap keputusan pembelian shampo merek pantene pada masyarakat labuhanbatuutara?

- Apakah daya tarik iklan televisi memiliki pengaruh terhadap keputusan pembelian shampo merek pantene pada masyarakat labuhanbatuutara?

- Apakah daya tarik brand ambassador dan daya tarik iklan televisi memiliki pengaruh terhadap keputusan pembelian shampo merek pantene pada masyarakat labuhanbatuutara?

\section{Tujuan Penelitian}

Berdasarkan paparan yang ada di dalam rumusan masalah, maka ada beberapa tujuan penelitian yang ingin didapatkan :

- Menganalisis pengaruh daya tarik brand ambassador terhadap keputusan pembelian shampo merek pantene pada masyarakat labuhanbatuutara.

- Menganalisis pengaruh daya tarik iklan televisiterhadap keputusan pembelian shampo merek pantene pada masyarakat labuhanbatuutara.

- Menganalisis pengaruh daya tarik brand ambassador dan daya tarik iklan televisi memiliki pengaruh terhadap keputusan pembelian shampo merek pantene pada masyarakat labuhanbatuutara.

\section{Studi literature}

\section{PengertianBrand ambassador}

Strategi kreatif yang dilakukan oleh perusahaan untuk meningkatkan minat dan menjaga atau membentuk citra serta memposisikan suatu produk terhadap konsumen biasanya melalui penunjukkan brand ambasador. Penunjukkan brand ambassador biasanya juga dilatarbelakangi oleh citra posistif yang dibawanya sehingga dapat mewakili citra produk secara keseluruhan.

Menurut Shimp (2006:455) brand ambassador adalah pendukung iklan atau juga yang dikenal sebagai bintang iklan yang mendukung produk yang diiklankan. 
Para brand ambassador diharapkan menjadi juru bicara merek agar cepat melekat di benak konsumen, sehingga konsumen mau membeli merek tersebut. Selain itu, selebriti bisa juga digunakan sebagai alat yang tepat untuk mewakili segmen pasar yang dibidik. Oleh sebab itu tidak heran ketika produk yang diiklankan menggunakan banyak selebriti, masing-masing akan mewakili segmen pasar yang dibidik. (Royan, 2006:122).

\section{Iklan}

Kata iklan (advertising) berasal dari bahasa Yunani, yang artinya kurang lebih adalah menggiring orang pada gagasan' (Durianto, 2007). Definisi iklan pada umumnya mengatakan. Iklan adalah komunikasi nonpersonal yang dibiayai dari pihak sponsor dengan menggunakan media massa untuk membujuk atau mempengaruhi khalayak. Definisi modern menjelaskan "Advertising is paid persuasive communication that uses nonpersonal mass media as well as other form of interactive communication to reach broad audiences to connect an identified sponsor with a target audience" (Wells \& Moriarty, 2009, p.5).

\section{KeputusanPembelian}

Keputusan pembelian merupakan kegiatan individu yang secara langsung terlibat dalam pengambilan keputusan untuk melakukan pembelian terhadap produk yang ditawarkan oleh penjual. Pengertian keputusan pembelian, menurut Kotler \& Armstrong (20012:90) dalam Ghazali (2010:88) adalah tahap dalam proses pengambilan keputusan pembeli di mana konsumen benar-benar membeli.Keputusan konsumen dalam pembelian selain dipengaruhi oleh karakteristik konsumen, dapat dipengaruhi oleh rangsangan perusahaan yang mencakup produk, harga, tempat dan promosi. Variabel-variabel diatas saling mempengaruhi proses keputusan pembelian sehingga menghasilkan keputusan pembelian yang didasarkan pada pilihan produk, pilihan merek, pilihan penyalur, waktu pembelian, jumlah pembelian (Kotler, 2012:70). Selain itu, Kualitas pelayanan merupakan tolak ukur dalam menentukan pembelian atau tidaknya seseorang, karena melalui kualitas pelayanan akan dapat menilai kinerja dan merasakan puas atau tidaknya mereka dengan layanan yang diberikan oleh perusahaan (Nizar, 2011:38).

\section{METODE PENELITIAN}

Lokasi penelitian dilakukan pada masyarakat kota pinang kabupaten Labuhanbatu Utara.

\section{Populasi}

Menurut Sugiyono (2012:173) populasi adalah wilayah generalisasi yang terdiri atas objek atau subjek yang mempunyai kualitas dan karakteristik tertentu yang ditetapkan oleh peneliti untuk dipelajari kemudian ditarik kesimpulan. Pada penelitian ini populasinya adalah masyarakat Kabupaten Labuhanbatu Utara.

\section{Sampel}

Menurut Sugiyono (2012:174), sampel adalah bagian dari jumlah dan karakteristik yang dimiliki oleh populasi tersebut. 
Jurnal Ecobisma Vol 2 No. 1 Jan 2015

TeknikpengambilansampeldalampenelitianiniadalahSimple

Random

yang
Sampling, adadalampopulasiitu.

UntukmenentukanjumlahsampeldalampenelitianinimenggunakanRumusWibisono 2008.

$\mathrm{n}=\frac{\mathrm{Z} \alpha / 2 \cdot \sigma}{e}$

dimana $\quad \mathrm{n}=$ sampel

$\mathrm{Z} \alpha=$ nilai table $\mathrm{z}=0,05$

$\sigma \quad=$ standar deviasi populasi

$\mathrm{e}=$ taraf kesalahan $=5 \%(0,05)$

$\mathrm{n}=\frac{(1,96) \cdot(0,25)}{0,05}$

$\mathrm{n}=96,04=96$

Berdasarkan perhitungan diatas, maka sampel yang digunakan sebanyak 96 responden.

\section{Hasil Penelitian}

\section{Uji validitas}

Sebuah instrumen dikatakan valid jika mampu mengukur apa yang diinginkan, dan dapat mengungkap data dari variabel yang diteliti secara tepat. Tinggi rendahnya validitas instrumen menunjukkan sejauh mana data yang terkumpul tidak menyimpang dari gambaran tentang variabel yang dimaksud.

1. Variabel daya tarik brand ambassador

Tabel 1

Validitas daya tarik brand ambassador

\begin{tabular}{|l|l|l|l|}
\hline & $\begin{array}{l}\text { Corrected Item- } \\
\text { Total Correlation }\end{array}$ & r-tabel & Keterangan \\
\hline X1.1 & 0,656 & 0,361 & Valid \\
\hline X1.2 & 0,645 & 0,361 & Valid \\
\hline X1.3 & 0,450 & 0,361 & Valid \\
\hline X1.4 & 0,445 & 0,361 & Valid \\
\hline X1.5 & 0,450 & 0,361 & Valid \\
\hline
\end{tabular}

Sumber : Data diolah, 2018

Dari tabel 1 menunjukkan bahwa semua pernyataan memiliki nilai total item corralation lebih dari r-tabel 0,361. Hal ini menunjukkan bahwa semua instrumen valid.

2. Variabel daya tarik iklan 
Tabel 2

Validitas daya tarik iklan

\begin{tabular}{|l|l|l|l|}
\hline & $\begin{array}{l}\text { Corrected Item- } \\
\text { Total Correlation }\end{array}$ & r-tabel & Keterangan \\
\hline X2.1 & 0,542 & 0,361 & Valid \\
\hline X2.2 & 0,422 & 0,361 & Valid \\
\hline X2.3 & 0,454 & 0,361 & Valid \\
\hline X2.4 & 0,422 & 0,361 & Valid \\
\hline X2.5 & 0,428 & 0,361 & Valid \\
\hline
\end{tabular}

Sumber : Data diolah, 2018

Dari tabel 2 menunjukkan bahwa semua pernyataan memiliki nilai total item corralation lebih dari r-tabel 0,361. Hal ini menunjukkan bahwa semua instrumen valid.

3. Variabel keputusan pembelian

Tabel 3

Validitas keputusan pembelian

\begin{tabular}{|l|l|l|l|}
\hline & $\begin{array}{l}\text { Corrected Item- } \\
\text { Total Correlation }\end{array}$ & r-tabel & Keterangan \\
\hline Y.1 & 0,426 & 0,361 & Valid \\
\hline Y.2 & 0,452 & 0,361 & Valid \\
\hline Y.3 & 0,441 & 0,361 & Valid \\
\hline Y.4 & 0,378 & 0,361 & Valid \\
\hline Y.5 & 0,465 & 0,361 & Valid \\
\hline
\end{tabular}

Sumber : Data diolah, 2018

Dari tabel 3 menunjukkan bahwa semua pernyataan memiliki nilai total item corralation lebih dari r-tabel 0,361. Hal ini menunjukkan bahwa semua instrumen valid.

\section{Uji Reliabilitas}

Uji reliabilitas dimaksudkan untuk mengetahui sejauh mana hasil pengukuran tetap konsisten atau stabil dari waktu ke waktu apabila dilakukan pengukuran dua kali terhadap gejala yang sama dengan menggunakan alat pengukur yang sama. Reliabilitas sebagai konsistensi antar pengukuran-pengukuran secara berurutan, dengan demikian uji reliabilitas dilakukan untuk menunjukkan sejauh mana suatu alat pengukur atau kuesioner dapat dipercaya atau diandalkan. 
Tabel 4.

Rekapitulasi Hasil Uji Reliabilitas

\begin{tabular}{|l|l|l|l|l|}
\hline No & Variabel & $\begin{array}{l}\text { Cronbach's } \\
\text { Alpha }\end{array}$ & Koefisien & Keputusan \\
\hline 1 & $\begin{array}{l}\text { Daya tarik brand } \\
\text { ambassador }\end{array}$ & 0,668 & 0,60 & Reliabel \\
\hline 2 & Daya tarik iklan & 0,734 & 0,60 & Reliabel \\
\hline 3 & Keputusan pembelian & 0,752 & 0,60 & Reliabel \\
\hline
\end{tabular}

Sumber: Data diolah, 2018

Berdasarkan tabel 4. diatas terlihat bahwa ketiga variabel yaitu daya tarik brand ambassador $\left(\mathrm{X}_{1}\right)$, daya tarik iklan $\left(\mathrm{X}_{2}\right)$, dan keputusan pembelian $(\mathrm{Y})$ diatas menunjukkan hasil yang sangat reliabel dengan nilai alpha $>0,60$. Sehingga dari nilai alpha diatas, maka item-item pada variabel diatas dapat digunakan untuk pengukuran selanjutnya.

\section{Uji Normalitas}

Uji normalitas merupakan persyaratan penting yang harus terpenuhi dalam analisis regresi. Uji ini digunakan untuk mengetahui apakah dalam sebuah model regresi, variabel dependen memiliki distribusi normal atau tidak.

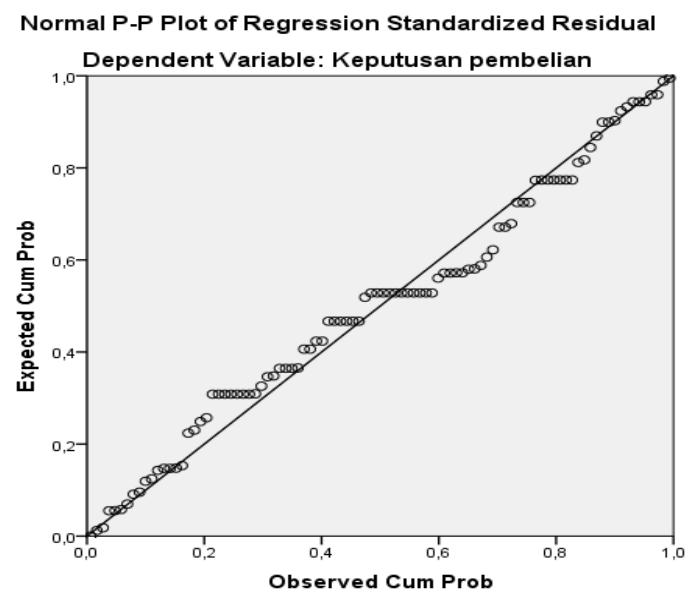

\section{Gambar.1}

\section{Uji Normalitas}

Dari gambar diatas dapat dilihat bahwa data menyebar disekitar diagram dan mengikuti model regresi sehingga dapat disimpulkan bahwa data yang diolah merupakan data yang berdistribusi normal, maka model regresi memenuhi asumsi normal.

\section{Uji Multikolinearitas}

Uji multikolinearitas digunakan untuk menguji adanya hubungan linear yang sempurna (mendekati sempurna) antara beberapa atau semua variabel bebas. 
Tabel 5

Coefficients $^{\mathrm{a}}$

Uji Multikolinearitas

\begin{tabular}{|ll|l|l|}
\hline \multirow{2}{*}{ Model } & & \multicolumn{2}{|l|}{ Collinearity Statistics } \\
\cline { 4 - 5 } & & Tolerance & VIF \\
\hline 1 & $\begin{array}{l}\text { (Constant) } \\
\text { Daya tarik brand } \\
\text { ambassador } \\
\text { Daya tarik iklan }\end{array}$ &, 839 & 1,066 \\
& &, 847 & 1,066 \\
\hline
\end{tabular}

a. Dependent Variable: Keputusan pembelian

Dasar pengambilan keputusan berdasarkan nilai tolerance:

Tolerance $>0,1$ makatidakterjadimultikolinearitas

Tolerance $<0,1$ makaterjadimultikolinearitas

Dasar pengambilan keputusan berdasarkan nilai VIF:

VIF $<10$ makatidakterjadimultikolinearitas

VIF $>10$ makaterjadimultikolinearitas

Dari tabel uji multikolinearitas diketahui bahwa nilai tolerance daya tarik brand ambassador yaitu $0,839>0,1$ maka tidak terjadi multikolinearitas , dan daya tarik iklan yaitu $0,847>0,1$ maka tidak terjadi multikolinearitas.

Berdasarkan uji multikolinearitas diketahui bahwa nilai VIF dari daya tarik brand ambassador yaitu 1,066< 10 maka tidak terjadi multikolinearitas,dan nilai VIF daya tarik iklan yaitu 1,066< 10 maka tidak terjadi multikolinearitas.

\section{Uji Heteroskedastisitas}

Uji heteroskedastisitas digunakan untuk mendeteksi apakah dalam model regresi terjadi ketidaksamaan varian dari residual satu pengamatan ke pengamatan lain. 


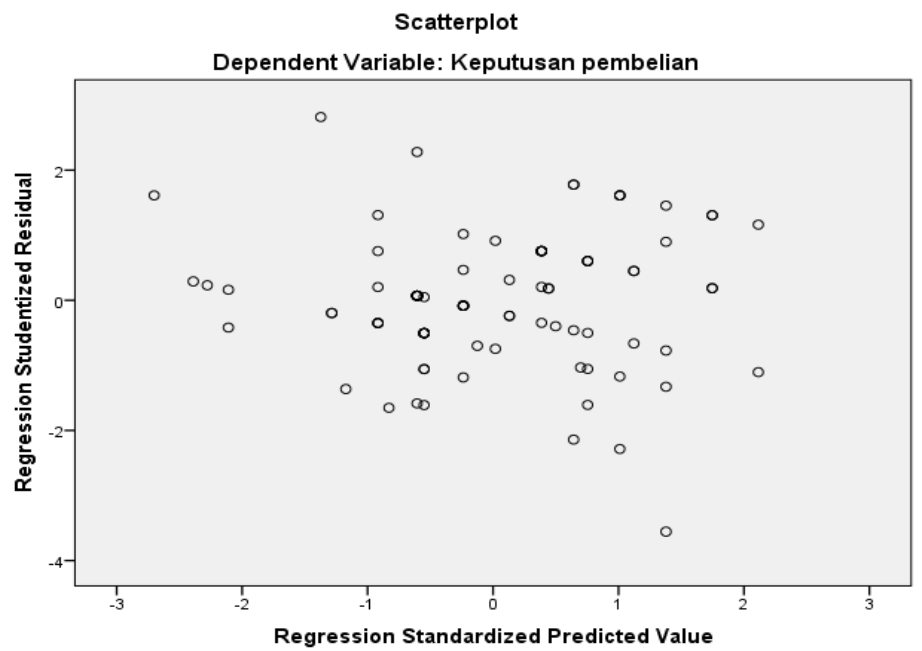

\section{Gambar .2}

\section{Uji Heteroskedastisitas}

Dari gambar diatas dapat diketahui bahwa titik yang ada tidak membentuk suatu pola tertentu seperti titik-titik menyebar diatas dan dibawah angka 0 pada sumbu $\mathrm{Y}$, maka tidak terjadi heteroskedastisitas.

\section{Hasil Analisis Regresi Berganda}

Analisis ini digunakan untuk mengetahui pengaruh variabel bebas (daya tarik brand ambassador dan daya tarik iklan) terhadap variabel terikat (keputusan pembelian). Hasil analisis regresi sebagai berikut:

\section{Tabel 6}

\section{Hasil Analisis Regresi Linear Berganda}

\section{Coefficients $^{\mathrm{a}}$}

\begin{tabular}{|c|c|c|c|c|c|c|}
\hline \multirow[b]{2}{*}{ Model } & & \multicolumn{2}{|c|}{$\begin{array}{l}\text { Unstandardized } \\
\text { Coefficients }\end{array}$} & \multirow{2}{*}{\begin{tabular}{|l} 
Standardized \\
Coefficients
\end{tabular}} & \multirow[b]{2}{*}{$\mathrm{t}$} & \multirow[b]{2}{*}{ Sig. } \\
\hline & & B & Std. Error & & & \\
\hline 1 & (Constant) & 3,224 & 2,360 & & 4,180 &, 000 \\
\hline & $\begin{array}{l}\text { Daya tarik brand } \\
\text { ambassador }\end{array}$ &, 047 &, 044 &, 183 & 3,815 &, 000 \\
\hline & Daya tarik iklan &, 054 &, 016 &, 223 & 3,151 &, 000 \\
\hline
\end{tabular}

a. Dependent Variable: Keputusan pembelian

Hasil pengolahan komputer dapat diketahui persamaan koefisien regresi linier berganda yang diperoleh sebagai berikut:

$\mathrm{Y}=3,224+0,047 \mathrm{X}_{1}+0,054 \mathrm{X}_{2}$

Persamaan regresi berganda tersebut dijelaskan sebagai berikut: 
Nilai konstanta 3,224 memberi art ibahwa apabila daya tarik brand ambassador $\left(X_{1}\right)$, dan daya tarik iklan $\left(\mathrm{X}_{2}\right)$ sama-sama tetap pada nilai nol atau konstan, maka keputusan pembelian $(\mathrm{Y})$ yang dihasilkan bernilai3,224.

Daya tarik brand ambassador berpengaruh positif dan signifikan terhadap keputusan pembelian denga nkoefisien regresi sebesar 0,047. Artinya apa bila daya tarik brand ambassador nai k0,04 7 maka keputusan pembelian juga akan naik sebesa r0,047.

Daya tarik iklan berpengaruh positif dan signifikan terhadap keputusan pembelian dengan koefisien regresi sebesar 0,054. Artinya apabila daya tarik iklan naik 0,054 maka keputusan pembelian juga akan naik sebesar 0,054.

\section{Koefisien Determinasi $\left(\mathbf{R}^{\mathbf{2}}\right)$}

Analisis ini digunakan untuk mengetahui seberapa besar sumbangan atau pengaruh yang diberikan variabel bebas terhadap variabel terikat yang ditunjukkan dengan persentase. Hasil koefisien determinasi sebagai berikut:

\section{Tabel 7}

\section{Hasil Koefisien Determinasi $\left(\mathbf{R}^{2}\right)$}

Model Summary ${ }^{b}$

\begin{tabular}{|l|l|l|l|l|}
\hline Model & $\mathrm{R}$ & R Square & $\begin{array}{l}\text { Adjusted } \\
\text { Square }\end{array}$ & $\begin{array}{l}\text { Rtd. Error of the } \\
\text { Estimate }\end{array}$ \\
\hline 1 &, $587^{\mathrm{a}}$ &, 633 &, 122 & 1,122 \\
\hline
\end{tabular}

a. Predictors: (Constant), Daya tarik iklan, Daya tarik brand ambassador

b. Dependent Variable: Keputusan pembelian

Nilai koefisien determinasi $\left(\mathrm{R}^{2}\right)$ menunjukkan besarnya kontribusi pengaruh variabel bebas terhadap variabel terikat. Hasil perhitungan yang dihasilkan pada tabel 4.13 diatas menunjukkan nilai $\mathrm{R}^{2}=0,633$. Hal ini berarti menunjukkan bahwa sebesar $63,3 \%$ keputusan pembelian dipengaruhi oleh daya tarik ambassador dan daya tarik iklan sedangkan sisanya sebesar 36,7\% dipengaruhi oleh variabel lain yang tidak diteliti.

\section{Uji Hipotesis Secara Simultan (Uji F)}

Uji F digunakan untuk mengetahui signifikans pengaruh variabel bebas secara bersamasama terhadap variabel terikat. Hasil uji F sebagai berikut:

\section{Tabel 8}

\section{Hasil Uji F}

ANOVA $^{\mathrm{a}}$

\begin{tabular}{|ll|l|l|l|l|l|}
\hline Model & & Sum of Squares & df & Mean Square & F & Sig. \\
\hline 1 & Regression & 54,445 & 2 & 27,413 & 10,456 &, $000^{\mathrm{b}}$ \\
& Residual & 308,712 & 93 & 3,232 & & \\
& Total & 355,332 & 95 & & & \\
\hline
\end{tabular}

a. Dependent Variable: Keputusan pembelian

b. Predictors: (Constant), Daya tarik iklan, Daya tarik brand ambassador 
Sumber: Data diolah,2018

Nilai F hitung $(10,456)>$ dari nilai $\mathrm{F}$ tabel $(2,47)$ dengan nilai signifikan $0,000<0,05$ maka Ho ditolak sehingga ada pengaruh yang signifikan daya tarik brand ambassador dan daya tarik iklan secara simultan terhadap keputusan pembelian shampo merek pantene pada masyarakat labuhanbatuutara.

\section{Pembahasan}

Menurut Shimp (2006:455) brand ambassador adalah pendukung iklan atau juga yang dikenal sebagai bintang iklan yang mendukung produk yang diiklankan.Hasil pengujian koefisien daya tarik brand ambassador terhadap keputusan pembelian shampo merek pantene pada masyarakat labuhanbatuutara memiliki jalur positif sebesar 0,047 yang berarti semakin baik kualitas pelayanan akan meningkatkan keputusan pembelian. Nilai probabilitas (p) sebesar 0,000 yang berarti ada pengaruh signifikan daya tarik brand ambassador terhadap keputusan pembelian shampo merek pantene pada masyarakat labuhanbatuutara. Sesuai dengan penelitian yang dilakukan oleh Putra (2014). Pengaruh Brand ambassador terhadap brand image serta dampaknya terhadap keputusan pembelian (Survey pada pengguna LINE di Asia).

Menurut Kotler dan Amstrong (2012 : 454) iklan adalah segala bentuk penyajian dan promosi ide, barang atau jasa secara nonpersonal oleh suatu sponsor tertentu yang memerlukan pembayaran.

Hasil pengujian koefisien daya tarik iklan terhadap keputusan pembelian shampo merek pantene pada masyarakat labuhanbatuutara memiliki jalur positif sebesar 0,054 yang berarti semakin baik daya tarik iklan akan meningkatkan keputusan pembelian. Nilai probabilitas (p) sebesar 0,000 yang berarti ada pengaruh signifikan daya tarik iklan terhadap keputusan pembelian shampo merek pantene pada masyarakat labuhanbatuutara. Hal ini diperkuat dengan penelitian yang dilakukan oleh Wibowo (2012). Pengaruh iklan televisi dan harga terhadap keputusan pembelian sabun lux (survei pada pengunjung mega bekasi Hypermall).

\section{Kesimpulan}

Secaraparsialdaya tarik brand ambassador memiliki pengaruh positif terhadap keputusan pembelian shampo merek pantene pada masyarakat labuhanbatu utara sebesar 0,047 yang berarti semakin baik daya tarik brand ambassador akan semakin baik keputusan pembelian.

Secara parsial daya tarik iklan memiliki pengaruh positif terhadap keputusan pembelian shampo merek pantene pada masyarakat labuhan batu utaras ebesar 0,054 yang berarti semakin baik daya tarik iklan akan meningkatkan keputusan pembelian.

Secarasimultandaya tarik brand ambassador dan daya trik iklanberpengaruhpositif dan signifikan terhadap keputusan pembelian shampo merek pantene pada masyarakat labuhanbatu utara. 


\section{Saran}

Berdasarkan temuan hasil penelitian yang telah dikemukakan sebelumnya, maka untuk meningkatkan keputusan pembelian adalah sebagai berikut:

Hasil penelitian yang menunjukkan bahwa daya tarik brand ambassador dan daya tarik iklan secara simultan mempengaruhi keputusan pembelian hendaknya dapat dijadikan masukan dan bahan pertimbangan bagi perusahaan dalam merancang dan menentukan kebijakan pemasaran yang efektif dan efisien terutama dalam mempengaruhi konsumen. Dengan mengetahui dan memahami daya tarik brand ambassador dan daya tarik iklan yang menjadi pasar sasarannya maka perusahaana kan mengetahui apa yang dibutuhkan dan diinginkan oleh konsumen sehingga akan mengarahkan perusahaan pada penetapan kebijakan pemasaran yang efektif dan efisien terutama dalam rangka mempengaruhi konsumen dalam keputusan pembeliannya.

Mengingat variabel bebas dalam penelitian ini merupakan hal yang sangat penting dalam mempengaruhi keputusan pembelian diharapkan hasil penelitian ini dapat dipakai sebagai acuan bagi peneliti selanjutnya untuk mengembangkan penelitian ini dengan mempertimbangkan variabel- variabel lain yang merupakan variabel lain diluarvariabel daya tarik brand ambassador dan daya tarik iklan yang tercantum dalam penelitian.

\section{DAFTAR PUSTAKA}

Akbar, Panji, A. 2011. Analisis Pengaruh Kualitas Pelayanan, Harga, dan Lokasi Terhadap Keputusan Pembelian Sepeda Motor Honda (Study Kasu Pada Dealer Sepeda Motor Honda Di Kota Banjarnegara): skripsi. Fakultas Ekonomi Universitas Diponegoro: Semarang

Djatnika, Tjetjep. 2007. Komunikasi Pemasaran. Bandung : PT Remaja Rosdakarya.

Durianto.2007. Invasi Pasar Dengan Iklan Yang Efektif, Jakarta: Gramedi.

Ghazali M. R., 2010.Analisis Pengaruh Lokasi, Promosi Dan Kualitas Layanan Terhadap Keputusan Membeli (Warnet Warung Internet) XYZ Jl.Singosari, Kota Semarang). Fakultas Ekonomi Universitas Diponegoro: Semarang

Ghozali, 2010, Pengaruh Faktor Budaya, Sosial, Pribadi, dan Psikologis Terhadap Keputusan Pembelian Pizza di Restoran Pizza Hut Malang, Skripsi FakultasEkonomi Universitas Negeri Malang.

Ghozali, Imam, 2010, Aplikasi Analisis Multivariate dengan Program SPSS,Penerbit Universitas Diponegoro, Semarang. 
Kotler, Philip dan Gary Amstrong. 2010. Marketing Management. Salemba Empat: Jakarta

Lembang, Rosvita, D. 2010. Analisis Pengaruh Kualitas Produk, Harga, Promosi dan Cuaca Terhadap Keputusan Pembelian The Siap Minum Dalam Kemasan Merek The Botol Sostro (Studi Kasus Pada Mahasiswa Fakultas Ekonomi S1 Regular II Universitas Diponegoro). Fakultas Ekonomi universitas diponegoro: Semarang.

Lea-Greenwood, Gaynor. 2012. Fashion Marketing Communications E-book. Somerset, NJ, USA: Wiley.

Nizar, Rifki K. 2011. Analisis Pengaruh Harga, Kualitas Layanan, dan Lokasi Terhadap Keputusan Pembelian Minyak Tanah Non Subsidi (Studi Kasus Pada Pangkalan Minyak Tanah Di Jalan Gor No 129 Kudus). Fakultas Ekonomi universitas diponegoro: Semarang.

Pamujo N. Yuga. 2011.Analisis Pengaruh Atribut Produk, Bauran Promosi, Dan Kualitas Pelayanan Terhadap Keputusan Pembelian Produk Merchandise (Studi Pada Kedai Digital 7 Di Semarang):skripsi. Fakultas Ekonomi Universitas Diponegoro: Semarang.

Royan, Frans. 2006. Marketing Celebrities. PT. Elex Media Komputindo. Jakarta.

Shimp, Terence A. 2006. Periklanan Promosi Aspek Tambahan Komunikasi Pemasaran. Edisi 5. Jilid 1. Alih Bahasa : Revyani Sjahrial dan Dyah Anikasari. Erlangga. Jakarta.

Santoso, S., 2007. SPSS Statistik Multivariat. Elex Komputindo KelompokGramedia, Jakarta.

Schiffman, Leon dan Leslie Lazar Kanuk 2006, Perilaku konsumen. Intan Sejati: Klaten

Setiadi, Nugroho. 2006. Perilaku Konsumen Konsep dan Implikasi untuk Strategi dan Penelitian Pemasaran. Kencana: Bandung.

Sekaran, Uma, 2009, Metodologi Penelitian Untuk Bisnis, Terjemahan Kwan MenYon, Salemba Empat, Jakarta.

Shandi Agil P. 2011. Analisis Dimensi Kepercayaan Merek Terhadap Loyalitas Merek Pengguna Kartu Indosat Im3 di Kota Semarang: Skripsi. Fakultas Ekonomi Universitas Diponegoro: Semarang.

Sugiyono. 2012. Metode Penelitian Bisnis. Alfabeta: Bandung

Suwandi, Imam M. 2007. Seri Manajemen Pemasaran. www.oecenomicus.files. wordpress.com. Diakses tanggal 16 Januari 2012. 
Sumarwan, Ujang. 2007. PerilakuKonsumen, TeoridanPenerapannya

Santoso, Singgih.2007.BukuLatihan SPSS Statistik Parametrik.PT Elex Media Komputindo, Jakarta.

Umar, Husein, 2008, Riset Strategi Perusahaan, Erlangga, Jakarta

Umi Narimawati (2008), Riset Manajemen Sumber Daya manusia Aplikasi Contoh dan Perhitungannya. Jakarta: Agung Media.

Wibisono, Y. 2008. Membedah Konsep\& Aplikasi CSR, Gresik, Fascho Publishing

Wells, W., Burnett, J., \& Moriarity, S. 2009. Advertising: Principles and Practice (7th ed). New Jersey: Prentice Hall, Englewood Cliffs. Majalah: Sugiarto, Eka, 15-28 Juli 2010

Yusuf, Muhammad. 2011. Analisis Pengaruh Promosi, Harga, Kualitas Produk dan Layanan Purna Jual Terhadap Keputusan Pembelian Sepeda Motor Honda (Studi Kasus Pada Mahasiswa Fakultas Ekonomi Universitas Diponegoro Semarang). Fakultas Ekonomi universitas diponegoro: Semarang. 